\title{
How Does the Passenger Perception Aware to the Safety Aspects in Case on Passenger Ship?
}

\author{
Imam Fahcruddin ${ }^{1, a, *}$, Retno S. Wulandari ${ }^{1}$ and Antoni Arif Pribadi ${ }^{2, b}$ \\ ${ }^{1}$ Department of Marine Engineering, Sekolah Tinggi Ilmu Pelayaran, Jakarta, Indonesia \\ ${ }^{2}$ Department of Nautical Studies, Sekolah Tinggi Ilmu Pelayaran, Jakarta, Indonesia \\ a.imam_fahcruddin@dephub.go.id, b. antoni_arif@dephub.go.id \\ *corresponding author
}

Keywords: accident, gap analysis, passenger ship, safety.

Abstract: The numbers of ship accidents which had occurred at passenger ships in 2013 until 2017 are still remaining a question to the passengers on how they aware of the safety aspects during voyage. The passenger on board is one of the factors considered for the successful mitigation during in emergency situation. Therefore, the passenger at certain level needs to familiarize the safety aspects on passenger ship. The aim of this research is to analyze the gap between perception and expectation of the ship passenger based on safety aspects by using gap analysis method. The survey through questionnaire was conducted for 105 passengers of passenger ship at Tanjung Priok Terminal, Jakarta. The result indicates that there are some gap found for all variables under first category group. The gap was also found under second and third category group. Furthermore, the result gives the important consideration for developing approaches to prevent accident that focus on the operative ways dealing with the safety aspects awareness of the passenger ship.

\section{Introduction}

Two days after the ferry collided and sank, 82 people remained unaccounted for Sunday in waters, 38 peoples dead and rescued another 750 passengers. The passenger ship MV St. Thomas Aquinas collided with cargo ship the Sulpicio in the Mactan Channel about 2 miles northwest of Cebu City, the capital of Cebu province in August 2013 [5]. Other ship accident, the ferry collided with a cargo vessel and sank within minutes on the Padma river, the second deadly boat accident happen in a fortnight in the country, which has a history of ferry tragedies at February 2015. The ferry MV Mostofa was overcrowded with about 70-150 passengers sank in a Bangladesh river leaving at least 41 people including 11 children dead as rescuers searched for missing passengers [10].

The similar accident occurred in April 2014 at South Korean vessel. The Sewol vessel was carried 476 persons when it was capsized off the southwestern island of Jindo. The victims was counted 304 loss of lives and of those, 250 were student [4]. In Januari 2017, the KM Zahro Express ferry carried more than 200 passengers, caught by fire during its way to Tidung Island, Thousand Islands Indoneisa. The National Disaster Mitigation Agency (BNPB) reported 23 passengers were killed while 17 peoples suffered injuries. It was further said 194 passengers survived the incident while 17 others were reported still missing [12]. The Police already stated that the Master of KM Zahro Express as a suspect being considered to meet two elements of evidence, such as the ship's safety equipment and the responsibility on safety, security and the property of vessel, seafarer \& cargo. Later on, KM. 
Mutiara Sentosa which also caught by fire in Masalembu Island in May 2017, caused 5 peoples died [3]. The result of the investigation from the KNKT said that the fire came from the lower deck from the truck. There were also differences from the numbers on the manifest to the number of peoples evacuated [9].

The facts that found from the above ship accident is the numbers of lost lives passenger or missing passengers. We may say that the risk of accidents on passenger or ferry ship cause some critical question to the passengers. The questions raised is "Why there was numerous number of passengers that found missing? Did they really aware of the safety aspects during voyage? Did the passengers have sufficient understanding on how to abandon the ship in case of emergency? Did they have sufficient time to escape from the ship? Those questions lead to do this research, the questions which need to be answered on this research. The objective of this research is to analyze the safety knowledge of the passenger during voyage by using gap analysis method.

\section{Research Methodology}

To start with the research methodology, the term of safety needs to be clarified in the beginning. The safety is a human perceived quality that determines to what extend the management, engineering and operation of a system is free of danger to life, property and the environment [7]. Meaning that the underlined words of free of danger to life become the key aspect regarding safety. Another definition, safety is "the state of not being exposed to danger, a protective device (as on a weapon) to prevent accidental operation" [8]. Based on those definitions, safety is really related to the perception of human towards a thing. For instance, related to the voyage on board ship, the human will behave a safety matter regarding their perception towards safety on board ship.

A research related to the safety perception showed that even though the overall safety knowledge of the passengers can be stated as good, but there are some differences between groups of passengers [6]. Younger passengers and passengers on shorter trips generally have less safety knowledge than older passengers and passengers on longer trips. Their study also conclude the effects of two different formats on presenting safety relevant information due to passengers' perception of trust, safety and risk on board. Another research identified five safety perception themes [1]. The results specify that passenger's perception safety through the architecture of the passenger ship, the life-saving appliances, communications, emotions and other people. It could be stated that the safety research on passenger ship design, where human perceptions and reactions to the surrounding environment significantly affect their behavior.

This research is a quantitative descriptive study using the survey approach. The research sample, consisting of 105 respondents, was selected by means of the accidental sampling technique. The data were collected through questionnaires. The analysis applied is the Gap Analysis and Importance Performance Analysis (IPA).

The questionnaire survey consists of the questions of general information of the respondent. Then, the questions asked respondents to rate the level of perception and expectation of each variable. To extract the level of perception the respondents were asked to rate each variable on the five - point using Likert Scale, varying from "strongly disagree" (1) to "strongly agree" (5). Whereas for the level of expectation, the five - point using Likert Scale are: varying form "strongly unnecessary" (1) to "strongly necessary" (5).

A questionnaire survey was designed into three categories. The first category is related to the safety aspect during on board ship which consists of 16 variables as indicated on the Table I. The variable 2 to variable 10 regards to the general safety on board ship. Followed by variable 11 to variable 13 that related to the live saving equipment and the variable 14 to variable 16 relates to the fire extinguisher. The questionnaire is based on the practical safety on board and the requirements of 
International Convention on Safety of Live at Sea (SOLAS) 1974. The questionnaire items as they are treated as the variables emphasis on the general safety aspects on board ship, live saving equipment for sea survival and fire extinguisher for fighting fire.

Variable 2 refers to Safety of Life at Sea (SOLAS) Chapter III-Life saving appliances and arrangements. Part B-Requirements for ships and life saving appliances, Regulation 27-Information on passengers No.1; All persons on board all passengers ships shall be counted prior to departure. Variable 3 to variable 10 refers to SOLAS Chapter III, Part B, Section V-Miscellaneous, Regulation 37-Muster list and emergency instruction No.1; the muster list shall specify details of the general emergency alarm and public address system of the code and also action to be taken by crew and passengers when its alarm is stuned. The muster list shall also specify how the order to abandon ship will be given. Variable 11 to variable 13 refers to SOLAS Chapter III, Part B, Section I-Passengers ships and cargo ships, Regulations 7-Personal life-saving appliances No.2-Lifejackets. Variable 14 to variable 16 refers to SOLAS Chapter II-2-Construction, fire protection, fire detection and fire extinction. Part C, No.3-Portable fire extinguisher.

Table 1: The Variables Under First Group Categories

\begin{tabular}{|c|l|}
\hline \hline Variable & \multicolumn{1}{c|}{ Description of Variable } \\
\hline V2 & The luggage is appropriately checked \\
\hline V3 & The sign to passenger room is clearly visible \\
\hline V4 & The sign direction for muster station is clearly visible \\
\hline V5 & I regonize the muster station clearly \\
\hline V6 & The alarm of summoning passenger is clearly identified \\
\hline V7 & The public adressor is heard clearly \\
\hline V8 & The guidance for surviving in the emergency is clearly understood \\
\hline V10 & Evacuation information is given by crew properly \\
\hline V11 & Identity of crew is easly identified \\
\hline V12 & Life jacket location is identified and nearby me \\
\hline V13 & The guidance of using lifejacket is easly understood \\
\hline V14 & Fire extinguisher is identified and nearby me \\
\hline V15 & The guidance of using fire extinguisher is easly understood \\
\hline V16 & The use of fire extingusher is informed by crew \\
\hline
\end{tabular}

The second category of questionnaire survey consists of 9 variables which related to the knowledge of passengers before and after having safety demo identified with VC symbols. The variables asked the knowledge of the passenger in case the emergency situation will occur. The detail of variables is arranged as follows:

- VC1 (In emergency situation do you know where is route);

- VC2 (In emergency situation do you know what is alarm signal);

- $\operatorname{VC3}$ (In emergency situation do you know how to take lifejacket);

- VC4 (In emergency situation do you know how to take lifebuoy);

- VC5 (In emergency situation do you know how to use lifejacket);

- VC6 (In emergency situation do you know how to use lifebuoy);

- VC7 (In emergency situation do you know how to find first aid); 
- $\operatorname{VC} 8$ (In emergency situation do you know how to find alarm button);

- VC9 (In emergency situation do you know where is route).

The last category of the questionnaire survey is related to the trust of the passenger during voyage to the safety of ship. The variables consist of four questions due to the trust of the passenger to accidents such as collision (VD1), fire (VD2), sinking (VD3), and emergency situation (VD4).

The survey was conducted at passenger terminal of Tanjung Priok, Port of Jakarta during June to July 2017. Several manners were used to motivate the questionnaires to the respondents. Nevertheless, to motivate the respondents to participate in the survey, face to face or direct delivery was preferred. Doing so improved the response rate. Gap analysis is used to determine the steps which are need to be taken for further movement from recent condition to the expected condition in the future. The gap analysis is also a means of comparison between actual performance and future performance. This gap analysis also identifies the actions plan to achieve the future performance [11]. Furthermore, the gap analysis method is used to analysis between the perception and expectation of passenger towards the safety aspect during voyage on board ship. The gap calculation is obtained from the mean score of expectation after deducted with mean score of perception.

Finally, the gap analysis method is implemented for three categories of variables groups, consist of the category of the perception and expectation of the safety matters, the category of when the emergency situation occur, and the category of the trust of passenger toward safe voyage on board ship.

\section{Results and Discussion}

The respondent profiles include the respondent's age, education background, employment status and travelling number by ship. The total number of respondents was 105 passengers. For the respondent age, there are $61 \%$ of passengers have age less than 31 years old, followed by $38 \%$ of passengers have middle age between 31 - 50 years old and small percentage for passenger's age more than 51 years old. Regarding to the educational background, there are $50 \%$ passengers graduated from senior high school and $40 \%$ graduated from higher education. Then $10 \%$ of respondents is categorized with other education background. Other profiles, regarding to the employment status, $61 \%$ of passenger worked for private sector and $11 \%$ worked as civil servant, and $15 \%$ of respondent are students. To the last respondent profile, the travelling number on the same route, the $65 \%$ of passengers have previous experience between once and three times. Meanwhile, those who experienced 4 to 6 times were only $26 \%$ passengers accounted and $5 \%$ respondents have experienced 7 to 9 times of travelling time.

The achievement the safety aspect quality based on the passenger measurement is determined by the measurement of the perception and expectation of the passenger on the variables group 1 as it is presented in Table 2.

Based on Table II, the safety aspect expectation from the passenger for all variables does not reach $100 \%$. It means that there is a gap between the expectation of the passenger towards the perception of passenger. The lower value means the gap is higher. It could be conluded that the quality of safety aspect did not meet the expectation of the passenger.

Furthermore, the conformity level measurement of the knowledge of passengers before and after having safety demo identified with VC symbols which is presented in Table 3.

In Table 3, it shown that the conformity level of the knowledge of the passenger in case the emergency situation occurred for 6 variable 1 did not meet $100 \%$. Therefore, the variables such as $\mathrm{VC} 1, \mathrm{VC} 2, \mathrm{VC} 4, \mathrm{VC} 7, \mathrm{VC} 8$ and $\mathrm{VC} 9$ did not meet the passenger expectation. Whereas the variables 
such as VC3, VC5, and VC6 can be easily identified by the passenger in case there is an emergency situation. The conformity level of last categories is presented on the Table 4 below.

Table 2: The Conformity Level of First Categories

\begin{tabular}{|c|c|c|c|c|}
\hline Variable & Mean of Perceptions & Mean of Expectations & Conformity Level & $\begin{array}{c}\text { Gap } \\
(\mathbf{P}-\mathbf{E})\end{array}$ \\
\hline V2 & 3.55 & 4.74 & $74.89 \%$ & -1.19 \\
\hline V3 & 3.82 & 4.52 & $84.51 \%$ & -0.7 \\
\hline V4 & 3.82 & 4.68 & $81.62 \%$ & -0.86 \\
\hline V5 & 3.92 & 4.60 & $85.22 \%$ & -0.68 \\
\hline V6 & 4.02 & 4.63 & $86.83 \%$ & -0.61 \\
\hline V7 & 3.89 & 4.54 & $85.68 \%$ & -0.65 \\
\hline V8 & 3.90 & 4.63 & $84.23 \%$ & -0.73 \\
\hline V9 & 3.71 & 4.68 & $79.28 \%$ & -0.97 \\
\hline V10 & 3.96 & 4.69 & $84.44 \%$ & -0.73 \\
\hline V11 & 3.95 & 4.73 & $83.51 \%$ & -0.78 \\
\hline V12 & 3.95 & 4.68 & $84.41 \%$ & -0.73 \\
\hline V13 & 3.87 & 4.72 & $81.99 \%$ & -0.85 \\
\hline V14 & 4.04 & 4.64 & $87.07 \%$ & -0.6 \\
\hline V15 & 3.84 & 4.68 & $82.05 \%$ & -0.84 \\
\hline V16 & 4.03 & 4.65 & $86.67 \%$ & -0.62 \\
\hline
\end{tabular}

Table 3: The Conformity Level of Second Categories

\begin{tabular}{|c|c|c|c|c|}
\hline Variable & Mean of Perceptions & Mean of Expectations & Conformity Level & $\begin{array}{c}\text { Gap } \\
(\mathbf{P}-\mathbf{E})\end{array}$ \\
\hline VC1 & 3.75 & 4.30 & $87.20 \%$ & -0.55 \\
\hline VC2 & 3.85 & 4.44 & $86.71 \%$ & -0.59 \\
\hline VC3 & 3.87 & 3.72 & $103.86 \%$ & 0.14 \\
\hline VC4 & 4.36 & 4.40 & $99.15 \%$ & -0.04 \\
\hline VC5 & 4.45 & 3.84 & $115.90 \%$ & 0.61 \\
\hline VC6 & 3.95 & 3.89 & $101.48 \%$ & 0.06 \\
\hline VC7 & 3.91 & 4.27 & $91.76 \%$ & -0.35 \\
\hline VC8 & 3.41 & 3.53 & $96.51 \%$ & -0.12 \\
\hline VC9 & 3.61 & 3.65 & $98.97 \%$ & -0.04 \\
\hline
\end{tabular}

Table 4: The Conformity Level of Last Categories

\begin{tabular}{|c|c|c|c|c|}
\hline Variable & Mean of Perceptions & Mean of Expectations & Conformity Level & $\begin{array}{c}\text { Gap } \\
(\mathbf{P}-\mathbf{E})\end{array}$ \\
\hline VD1 & 4.32 & 3.24 & $133.41 \%$ & 1.08 \\
\hline VD2 & 3.95 & 3.61 & $109.43 \%$ & 0.34 \\
\hline VD3 & 3.94 & 3.47 & $113.65 \%$ & 0.47 \\
\hline VD4 & 4.7 & 3.52 & $133.38 \%$ & 1.18 \\
\hline
\end{tabular}


Based on the Table IV, it showed that the suitability of the trust of the passenger during voyage to the safety of ship for every variable reaches more than $100 \%$. Therefore, the variables such as VD1, VD2, VD3 and VD4 have been known by passenger and can be tackled.

The gap analysis for the 15 variables categorized under first group is displayed on the Table 2 . The results showed that all respondents rate the variable 2 (check the luggage) as the most important gap, followed by variable 9 (Evacuation information is given by crew properly). Meanwhile, there are 8 variables have medium value of gap which includes:

- V13 (The use of lifejacket is informed by crew);

- V4 (The sign direction for muster station is clearly visible);

- V15 (The guidance of using fire extinguisher is easly understood);

- V11 (Life jacket location is identified and nearby me);

- V8 (The guidance for surviving in the emergency is clearly understood);

- V10 (Identity of crew is easly identified);

- V12 (The guidance of using lifejacket is easly understood);

- V3 (The sign to passenger room is clearly visible).

Further, 5 variables have the lower gap such as:

- V5 (I regonize the muster station clearly);

- V7 (The public adressor is heard clearly);

- V6 (The alarm of summoning passenger is clearly identified);

- V16 (The use of fire extingusher is informed by crew).

- V14 (Fire extinguisher is identified and nearby me).

Having the gap analysis result of the first category of the variables group, then the similar procedures were implemented to obtain the gap analysis of the second category of the variables group. The second category consists of 9 variables from VC1 to VC9. The gap analysis for the second category is presented in Table 3.

Importance Performance Analysis (IPA) in this research was conducted for all respondents. The result was obtained and plotted in the Cartesius diagram. The Cartesius diagram is reflected the safety aspect and presented in Figure 1.

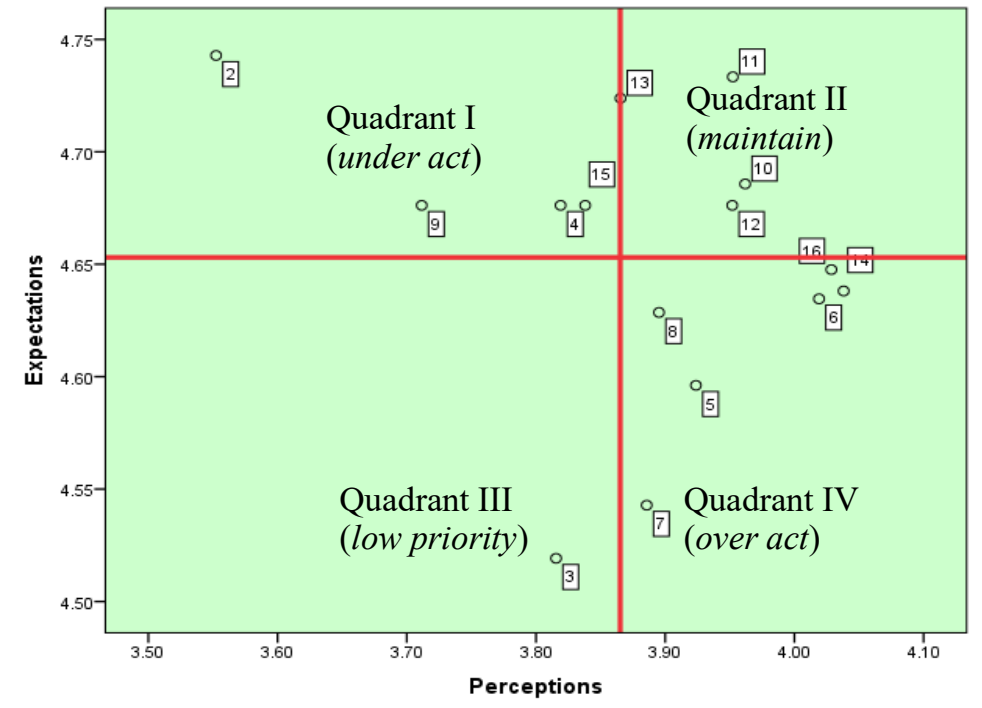

Figure. 1: Gap analysis for first group category 
Figure 1 shows that the concern of passenger toward safety aspect has 5 variables under quadrant I which need priority corrective action. Further, 3 variables are under quadrant II. One variable is under quadrant III and 6 variables are under quadrant IV.

The Cartesius diagram for the knowledge of passengers aspect before and after having safety demo is identified and presented in Figure 2.

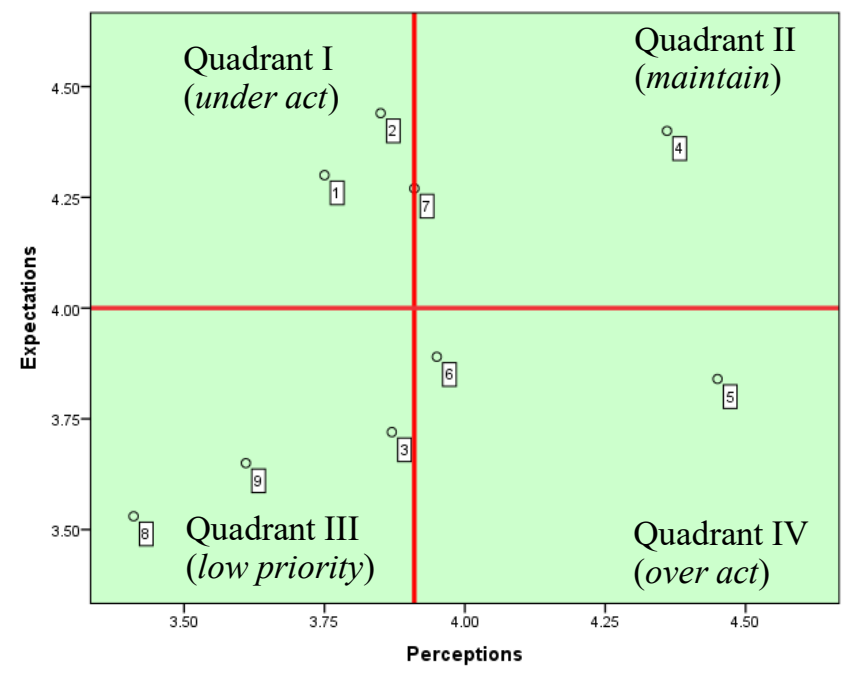

Figure 2: Gap analysis for second group category

Based on Figure 2, it shows that the knowledge aspect of the passenger in case of the emergency situation places the 3 variables under quadrant I and need priority corrective action. One variable is under quadrant II. 3 variables are under quadrant 3. Last, 2 variables are under quadrant IV. Further, the trust of the passenger during voyage to the safety of ship result is presented in Figure 3.

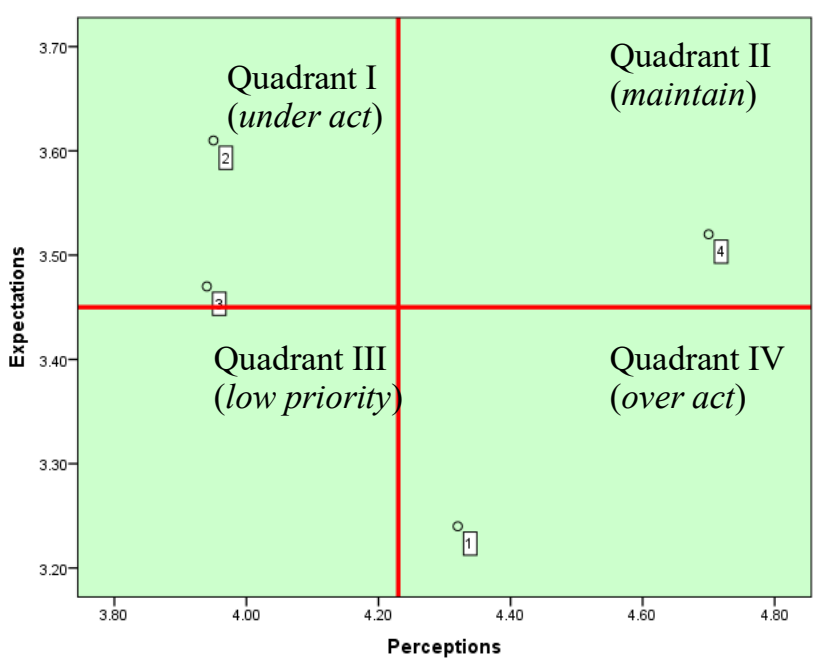

Figure 3: Gap analysis for last group category

It shows that 2 variables need priority corrective action. Then, one variable is occupied in quadrant II. There is also one variable under quadrant IV.

We could make conclusion that there are some variables under quadrant I which need to be followed by priority corrective action. For the first category of safety aspect, 5 variables are important 
and they require immediately corrective action. The knowledge level of the passenger during emergency situation aspect has 3 variables which require immediately corrective action. Then, for the trust of passenger during voyage, there are 2 variables which need to be considered. It also can be concluded that the education through safety brochure, safety pamphlet, safety drill, safety briefing need to be further modified to motivate the passenger for safety aspects.

\section{Acknowledgements}

The authors would like to be obliged to Sekolah Tinggi Ilmu Pelayaran Jakarta for providing the opportunity to conduct this research.

\section{References}

[1] Ahola, Markus, Pekka, M., Pentti, K., and Juhani, P. (2014). Perceiving safety in passenger ships - User studies in an authentic environment. Safety Science, 70, 222-232.

[2] Aksorn, T. \& Hadikusumo, B.H.W.(2007). Gap Analysis Approach for Construction Safety Program Improvement. Journal of Construction in Developing Countries, Vol. 12, No. 1, Universiti Sains Malaysia.

[3] CNN Indonesia. (2017). penumpang-km-mutiara-sentosa-1-sudah-dievkuasi. www.cnnindonesia.com. Retrieved June 10, 2017 from www.cnnindonesia.com/nasional/20170520094349-20-216076/penumpang-km-mutiarasentosa-1-sudah-dievkuasi/

[4] Dailymail.co.uk. (2016). http://www.dailymail.co.uk. Eerie-pictures-untouched-classroom-belonging-studentsteachers-killed-Sewol-ferry-disaster-South-Korea. Retrieved June 10, 2017 from http://www.dailymail.co.uk/news/article-3605976/Eerie-pictures-untouched-classroom-belonging-studentsteachers-killed-Sewol-ferry-disaster-South-Korea.html.

[5] Edition.cnn.com. (2013). Philippines ships collision. Retrieved June 10, 2017 from http://edition.cnn.com/2013/08/16/world/asia/philippines-ships-collision/index.html.

[6] Hystad, S.W., Oyeniyi S.O., and Jarle, E. (2016). Safe travel: Passenger assessment of trust and safety during seafaring. Transportation Research Part F, 38, pp. 29-36.

[7] Kuo, C. (2007). Safety Management and Its Maritime Application. London: The Nautical Institute.

[8] Merriam-webster.com. (n.d). safety.www.merriam-webster.com/ thesaurus. Retrieved June 10, 2017 (http://www.merriam-webster.com/thesaurus/safety).

[9] Nasional.tempo.co. (2017). www.nasional.tempo.co.km-mutiara-sentosa-i-terbakar-knkt-selidiki-truck-sumber-api. Retrieved June 10, 2017 from

[10]www.nasional.tempo.co/read/news/2017/05/21/058877324/km-mutiara-sentosa-i-terbakar-knkt-selidiki-trucksumber-api.

[11]Ndtv.com. (2015). 41 dead as bangladesh ferry sink. Retrieved June 102017 from https://www.ndtv.com/worldnews/41-dead-as-bangladesh-ferry-sinks-search-for-missing-countinues-741533.

[12]Suroto, A. (2015). Gap Analysis. http://sis.binus.ac.id. Retrieved June 10, 2017 (http://sis.binus.ac.id/2015/07/28/gap-analysis-analisa-kesenjangan/).

[13] The Jakarta Post. (2017). ministry-to-standardize-thousand-islands-service-after-zahro-express-incident." thejakartapost.com. Retrieved June 10, 2017 (www.thejakartapost.com/news/2017/01/02/ministry-to-standardizethousand-islands-service-after-zahro-express-incident.html 